\title{
THE EFFECT OF GIVING BOILED CHICKEN EGGS AND PAPAYA FRUIT ON THE IMPROVEMENT OF HEMOGLOBIN LEVELS IN ANEMIA STUDENTS
}

\author{
Dewi Susanti $^{1)}$, Faridah.Bd ${ }^{1)}$, Alsri Windra Doni' ${ }^{1)}$, Yuli Amalia ${ }^{1)}$ \\ ${ }^{1}$ Jurusan Kebidanan Poltekkes Kemenkes Padang \\ J1. Simpang Pondok Kopi Siteba Padang \\ E-mail: alsriwindradoni79@gmail.com
}

Submitted: 19 December 2019; Accepted: 2 January 2020

https://doi.org/10.36525/sanitas.2019.15

\begin{abstract}
Anemia in adolescent girls is quite high, the incidence of anemia nationally is $21.7 \%$. Anemia in adolescents if left untreated will continue into adulthood and contribute greatly to AKI, premature babies, and low birth weight babies. One way to prevent this can be done by consuming boiled chicken eggs and papaya fruit. The purpose of this study was to determine the effect of boiled chicken eggs and papaya fruit on increasing Hb levels in anemic female students of SMP Negeri 22 Kerinci in2019. This type of research was quasi experiment design of one group pretest posttest design with a sample of 16 respondents, purposive sampling sampling technique using the GCHB easy touch instrument and observation sheet. Univariate and bivariate data collection using paired t test. The results of the study average hemoglobin before treatment is $10.456 \mathrm{gr} / \mathrm{dL}$ and after treatment that is $12.412 \mathrm{gr} / \mathrm{dL}$. Paired sample t test obtained the average difference before and after treatment was 1.9563 gr / dL with $\mathrm{p}$ value $=0,000<0.05$. It was concluded that there was an effect of giving boiled chicken eggs and papaya to an increase in hemoglobin levels in anemic female students. Suggestions that female Kerinci Junior High School 22 Kerinci teachers who experience mild anemia to invite their students to consume boiled chicken eggs and papaya fruit as an alternative in dealing with mild anemia experienced by students.
\end{abstract}

Keyword : Boiled Chicken Eggs, Papaya, Hb Levels

This is an open access journal, and articles are distributed under the terms of the Creative Commons Attribution-NonCommercial-ShareAlike 4.0 License, which allows others to remix, tweak, and build upon the work non-commercially, as long as appropriate credit is given and the new creations are licensed under the identical terms.

(C)2019 Sanitas

\section{PENGARUH PEMBERIAN TELUR AYAM REBUS DAN BUAH PEPAYA TERHADAP PENINGKATAN KADAR HEMOGLOBIN PADA SISWI ANEMIA}

\begin{abstract}
ABSTRAK
Anemia pada remaja putri cukup tinggi, kejadian anemia secara nasional sebesar 21,7\%. Anemia pada remaja jika tidak tertangani akan berlanjut hingga dewasa dan berkontribusi besar terhadap AKI, bayi lahir prematur, dan bayi berat lahir rendah. Salah satu cara pencegahan bisa dilakukan dengan mengkonsumsi telur ayam rebus dan buah pepaya. Tujuan penelitian ini untuk mengetahui pengaruh pemberian telur ayam rebus dan buah pepaya terhadap peningkatan kadar Hb pada siswi anemia SMP Negeri 22 Kerinci Tahun 2019. Jenis penelitian ini quasi experiment rancangan one group pretest posttest design dengan jumlah sampel 16 orang responden, teknik pengambilan sampel purposive sampling menggunakan Instrumen alat easy touch GCHB dan lembar
\end{abstract}


observasi. Pengambilan data univariat dan bivariat menggunakan uji paired test.Hasil penelitian rata-rata hemoglobin sebelum perlakuan yaitu $10,456 \mathrm{gr} / \mathrm{dL}$ dan sesudah perlakuan yaitu $12,412 \mathrm{gr} / \mathrm{dL}$. Uji paired sample $\mathrm{t}$ test didapatkan rata-rata selisih sebelum dan sesudah perlakuan adalah $1,9563 \mathrm{gr} / \mathrm{dL}$ dengan $\mathrm{p}$ value $=0,000$ $<0,05$. Disimpulkan terdapat pengaruh pemberian telur ayam rebus dan buah pepaya terhadap peningkatan kadar hemoglobin pada siswi anemia. Saran agar para guru siswi SMP Negeri 22 Kerinci yang mengalami anemia ringan untuk mengajak siswinya mengkonsumsi telur ayam rebus dan buah pepaya sebagai salah satu alternatif dalam mengatasi anemia ringan yang dialami siswi.

Kata Kunci: Telur Ayam Rebus, Pepaya,Kadar Hb

\section{PENDAHULUAN}

Anemia adalah suatu kondisi medis dimana jumlah sel darah merah atau hemoglobin kurang dari normal. Anemia sebagian besar disebabkan oleh defisiensi zat besi. Anemia Defisiensi Besi (ADB) masih menjadi masalah kesehatan masyarakat sehubungan dengan prevalensinya yang tinggi dan dampaknya terhadap kesehatan ibu dan bayinya. Prevalensi ADB yang tinggi menyerang hampir seluruh kelompok masyarakat.(1,2)

Program intervensi dari pemerintah untuk mencegah anemia masih banyak terpusat pada kaum ibu hamil, padahal kaum remaja, khususnya perempuan juga perlu diberi perhatian lebih karena justru remaja perempuan nantinya merupakan calon ibu sehingga kejadian anemia dapat dicegah sedini mungkin. Remaja putri merupakan salah satu kelompok yang rawan menderita anemia. Anemia pada remaja putri sampai saat ini masih cukup tinggi, menurut WHO pada tahun 2013, prevalensi anemia didunia berkisar 40-88\%. Sedangkan menurut Kemenkes RI tahun 2013, jumlah penduduk usia remaja (10-19 tahun) di Indonesia sebesar $26,2 \%$ yang terdiri dari $50.9 \%$ anak laki-laki dan $49,1 \%$ anak perempuan. $(3,4)$

Prevalensi anemia secara nasional adalah sebesar 21,7\%. Sebesar 18,4\% terjadi pada laki-laki dan 23,9\% terjadi pada perempuan. Anemia defisiensi besi merupakan masalah gizi yang lazim di dunia dan menjangkit lebih dari 600 juta manusia. Prevalensi anemia secara global adalah sekitar 51\%. Prevalensi untuk balita sekitar 43\%, anak usia sekolah 37\%, pria dewasa $18 \%$ dan wanita tidak hamil 35\%. Berdasarkan kelompok umur, penderita anemia umur 5-14 tahun sebesar 26,4\% dan sebesar 18,4\% pada kelompok umur 15-24 tahun. Dari semua kelompok umur tersebut, wanita mempunyai resiko paling tinggi untuk menderita anemia terutama remaja putri. Kejadian anemia pada remaja putri umur 13-18 tahun dan 
wanita usia subur 15-49 tahun yaitu $22,7 \%$ total prevalensi anemia di Indonesia $(21,7 \%$ penduduk Indonesia). (5)

Anemia pada remaja menyebabkan kelelahan, menurunnya konsentrasi belajar sehingga prestasi belajar rendah dan dapat menurunkan produktivitas kerja. Selain itu juga dapat menurunkan daya tahan tubuh sehingga mudah terkena infeksi. Menurut Robertus tahun 2014, prevalensi anemia yang tinggi dikalangan remaja jika tidak tertangani dengan baik akan berlanjut hingga dewasa dan berkontribusi besar terhadap angka kematian ibu, bayi lahir prematur, dan bayi dengan berat lahir rendah. (3)

Sasaran program penanggulangan anemia gizi telah dikembangkan yaitu mencapai remaja putri SMP, SMA dan sederajat, serta wanita diluar sekolah. Menurut Survey Demografi Kesehatan Indonesia (SDKI) tahun 2012, prevalensi penyakit anemia sebanyak 75,9\% pada remaja putri. Data Survey Rumah Tangga (SKRT) tahun 2012 menyatakan bahwa prevalensi anemia pada remaja putri usia 10-18 tahun sebesar 50,5\%. (3)

Laporan program kesehatan reproduksi remaja Dinas Kesehatan Kota Jambi pada tahun 2011, menunjukkan bahwa kejadian anemia pada remaja putri berfluktuasi selama tiga tahun terakhir. Pada tahun 2009 kejadian anemia remaja putri (10-18 tahun) di wilayah kerja Dinas Kesehatan Kota Jambi sebesar 10,9 \%. Menurut Dinas Kesehatan Kerinci tahun 2017 prevalensi remaja putri yang mendapatkan tablet tambah darah 17,4\% dan jumlah remaja putri yang mendapatkan tablet tambah darah paling sedikit terdapat diwilayah kerja Puskesmas Sungai Pegehyaitu sebesar 9,8\%. (6)

Tahun 2001, WHO menetapkan bahwa anemia gizi besi dianggap terjadi jika kadar hemoglobin individu berada di bawah minus dua standar deviasi (-2SD) dari distribusi ratarata hemoglobin pada populasi normal untuk kelompok usia dan jenis kelamin yang sama. Penelitian mengenai anemia telah banyak dilakukan, baik pada kelompok usia prasekolah, remaja, ataupun wanita hamil, sebagai kelompok usia yang berisiko mengalami anemia. Menurut WHO pada tahun 2011, diketahui bahwa lebih dari seperempat remaja di negara- 
negara di Asia Tenggara (kecuali Thailand) mengalami anemia. Prevalensi remaja anemia di tiap negara bervariasi, yaitu antara $17-90 \% .(4)$

Zat besi merupakan mineral yang dibutuhkan tubuh untuk membentuk sel darah merah (hemoglobin). Sel darah merah mengandung hemoglobin yaitu protein yang membawa oksigen ke seluruh jaringan tubuh. Ketika seseorang tidak memiliki cukup sel darah merah atau jumlah hemoglobin dalam darah rendah maka tubuh tidak bisa mendapatkan oksigen sesuai kebutuhannya sehingga orang tersebut akan merasa lelah atau menderita gejala lainnya. $(1,6)$

Zat besi dalam makanan dapat berbentuk heme dan nonheme. Zat besi heme adalah zat besi yang berikatan dengan protein, banyak terdapat dalam makanan hewani misalnya daging, unggas, dan ikan. Zat besi nonheme ini umumnya terdapat dalam tumbuh-tumbuhan seperti serealia, kacang-kacangan, sayur-sayuran, dan buah-buahan. Zat besi heme diabsorpsi sebanyak 20-30\%, sebaliknya zat besi nonheme hanya diabsorbsi sebanyak 1-6\%. Hasil dari suatu penelitian menunjukkan bahwa sebanyak $37 \%$ zat heme dan $5 \%$ zat nonheme yang ada dalam makanan dapat diabsorpi dan ditingkatkan dengan adanya asupan vitamin C.(7)

Efek samping tablet besi berupa pengaruh yang tidak menyenangkan seperti rasa tidak enak di ulu hati, mual, muntah dan diare (terkadang juga konstipasi). Penyulit ini tidak jarang menyusutkan ketaatan pasien selama pengobatan berlangsung. Pengobatan dan pencegahan anemia bisa dilakukan dengan cara memakan makanan yang mengandung zat besi, baik yang berasal dari hewani (daging, ayam, ikan, hati, telur), maupun yang berasal dari nabati (sayuran yang berwarna hijau tua, kacang-kacangan, tempe dll).(8,9)

Telur merupakan salah satu makanan yang memiliki protein yang bermutu tinggi, karena telur memiliki susunan asam amino yang lengkap sehingga sering dijadikan patokan dalam menentukan mutu protein dari berbagai bahan pangan lainnya. Hemoglobin dalam darah terdiri dari asam amino dan zat besi, serta lipoprotein yang terdiri dari asam amino dan lemak.Telur juga memiliki sususan protein yang mudah diserap tubuh, selain itu telur juga 
makanan yang populer, murah dan banyak digunakan dalam pembuatan roti rumah tangga atau komersial. $(10,11)$

Telur juga mengandung vitamin B kompleks, serta vitamin A dan D (dalam kuning telur) dan mengandung banyak zat gizi yang sangat penting bagi kesehatan dan pencegahan penyakit. Telur merupakan makanan yang sangat baik bagi anak-anak maupun orang dewasa dan khususnya berguna sekali bagi para vegetarian. Penyajiannya pun beragam, dapat direbus, di goreng dan didadar. Namun pada bayi dan anak kecil, sebaiknya tidak diberi telur setengah matang tetapi telur rebus (matang), karena "ovomucoid" berpengaruh pada enzim tripsin bayi dan anak kecil yang lebih peka terhadap protein tersebut dibandingkan dengan orang dewasa.(12)

Sri Karyati dkk melakukan penelitian tentang Pengaruh Konsumsi Telur Terhadap Peningkatan Kadar Hemoglobin Pada Remaja yang Mengalami Anemia di Kudus. Hasil penelitian yang dilakukan dengan memberikan telur rebus selama 3 hari berturut-turut, terdapat perbedaan bermakna kenaikan $\mathrm{Hb}$ sebelum dan sesudah pemberian perlakuan kepada kelompok intervensi dengan selisih perubahan kadar Hb rata-rata sebesar 2-3 gr/dl. Hal ini sejalan dengan hasil penelitian Supiati,dkk terdapat perbedaan signifikan perubahan kadar $\mathrm{Hb}$ antara ibu nifas yang diberikan telur rebus dengan ibu nifas yang tidak diberikan telur rebus pada hari pertama dan hari ke-21 masa nifas dengan $\mathrm{t}$ hitung lebih kecil dari $\mathrm{t}$ tabel $(-7,032<-2042)$ dengan selisih perubahan kadar $\mathrm{Hb}$ pada ibu nifas rata-rata 2 gr $\% .(13,14)$

Saidin \& Saidin (1997) menjelaskan bahwa, penyerapan zat besi dalam tubuh memerlukan bantuan vitamin C. Sebuah studi pada siswi sekolah menengah atas di Cimahi dan Bandung menunjukkan bahwa intervensi pemberian satu butir pil zat besi ditambah dengan vitamin $\mathrm{C}$ satu kali dalam seminggu terbukti paling efetif dalam meningkatkan kadar hemoglobin siswi. Menurut Wardlaw \& Hampl (2007), asam organik seperti vitamin C dapat meningkatkan penyerapan zat besi non-heme. $(4,10)$ 
Vitamin $\mathrm{C}$ juga berperan untuk pembentukan kolagen yang sangat bermanfaat untuk penyembuhan luka.Vitamin $\mathrm{C}$ dapat diperoleh dengan mengonsumsi buah-buahan seperti jeruk, tomat, jambu, pisang, pepaya, sirsak dll. Menurut Kalie (2008), Pepaya (carica papaya l.) merupakan tanaman yang banyak tersebar di berbagai negara tropis termasuk Indonesia. Buah dari tanaman ini tergolong buah yang populer dan digemari oleh masyarakat Indonesia. Rasanya manis dan menyegarkan karena mengandung banyak air. Selain itu, harga buah pepaya juga juga relatif terjangkau di kalangan masyarakat.(15)

Pepaya merupakan salah satu buah-buahan yang sangat kaya akan gula buah, serat, berbagai vitamin (khususnya vitamin $\mathrm{C}$ dan $\mathrm{A}$ ), mineral, beta karotin (karotin) dan enzim (papain). Tidak hanya buahnya, daun pepaya pun memiliki kandungan vitamin C. Vitamin C berfungsi dalam pembentukan jaringan ikat atau bahan interseluler, pembentukan sel-sel darah merah, membantu perkembangan sel dan penyembuhan luka, serta proteksi demam. Vitamin C ini memiliki khasiat anti infeksi dan bisa membantu melindungi tubuh dari berbagai infeksi seperti masuk angin biasa. Jumlah vitamin C pada buah papaya adalah 78 mg, dan jumlah vitamin $\mathrm{C}$ yang dibutuhkan oleh remaja adalah 60 mg.(11,13,16,17)

Dalam penelitian Efektifitas Pemberian Telur dan Vitamin C terhadap Peningkatan Kadar Hemoglobin pada Ibu Hamil Trimester III di wilayah Kabupaten Sleman, Karuniawati dkk mendapatkan hasil kenaikan kadar Hb sebesar 1,71 gr\% dengan pemberian 2 butir telur ditambah dengan $75 \mathrm{mg}$ vitamin $\mathrm{C}$ dan 1,58 gr\% dengan pemberian 1 butir telur ditambah dengan 75 mg vitamin C, pada kelompok kontrol juga memiliki kenaikan Hb sebesar 1,07 gr\%. Penelitian ini membuktikan bahwa pemberian telur efektif untuk meningkatkan kadar hemoglobin pada ibu hamil yang mengalami anemia yang ditunjukkan dengan nilai signifikan sebesar 0,025.(18) Penelitian ini bertujuan untuk mengetahui pengaruh pemberian telur ayam rebus dan buah pepaya terhadap peningkatan kadar hemoglobin pada siswi anemia SMP Negeri 22 Kerinci Tahun 2019. 


\section{METODE PENELITIAN}

Jenis penelitian yang digunakan peneliti dalam melakukan penelitian adalah Quasi Experiment dengan Rancangan One Group Pretest Posttest yaitu rancangan yang tidak ada kelompok pembanding (kontrol), tetapi dilakukan observasi pertama (pretest) yang memungkinkan menguji perubahan-perubahan yang terjadi setelah adanya eksperimen (program). Populasi dalam penelitian ini adalah seluruh siswi kelas VIII yang berjumlah 82 orang di SMP Negeri 22 Kerinci. Perkiraan besar sampel pada penelitian ini dengan menggunakan Rumus Federrer yaitu:sebanyak 16 orang. (19)

Teknik pengambilan sampel menggunakan purposive sampling, yaitu teknik penetapan sampel dengan cara memilih sampel diantara populasi sesuai dengan yang dikehendaki peneliti sesuai kriteria inklusi.(19) Kriteria Inklusi antara lain : 1) Bersedia menjadi responden dengan mengisi informed consent, 2) Siswi yang mengalami anemia ringan, 3) Siswi yang sudah selesai menstruasi hari 3-7. Sedangkan kriteria eksklusi yaitu 1) Siswi yang tidak sedang mengkonsumsi tablet penambah darah, 2) Siswi yang memiliki alergi terhadap telur dan 3) Siswi yang mengalami penyakit infeksi seperti demam, diare atau infeksi parasit seperti cacingan. Pengumpulan data dilakukan dengan cara Pengukuran $\mathrm{Hb}$ dilakukan menggunakan alat easy touch dan lembar observasi. Responden diminta untuk mengisi lembar jadwal makan harian untuk melihat perbandingan nutrisi yang dikonsumsi oleh responden.

Tahap pelaksanaan dalam pengumpulan data, Peneliti memilih seorang tenaga kesehatan, yaitu bidan honorer di Puskesmas Sungai Pegeh sebagai enumerator. Subjek yang bersedia menjadi responden dilakukan pemeriksaan Hb kepada 25 orang siswi pada minggu pertama dan 13 orang siswi pada minggu kedua dan dicatat. Kemudian Peneliti menandatangani informed consent yang telah disiapkan peneliti, didapatkan 14 orang responden pada minggu pertama dan 6 orang responden pada minggu kedua. Peneliti melakukan pemeriksaan $\mathrm{Hb}$ pretest pada hari senin, dicatat dan peneliti/enumerator memberikan 1 potong pepaya 100 gr yang telah ditimbang serta dikemas dan 1 butir telur dengan jarak pemberian 15 menit yang diberikan di pagi hari selama 6 hari berturut-turut 
pada jam 07.30-08.00 WIB serta memastikan responden memakannya. Jarak pemberian tersebut diharapkan telah meningkatkan keasamaan lambung yang berguna untuk meningkatkan daya larut besi. Kekurangan asam dalam lambung atau penggunaan obatobatan yang bersifat basa seperti antasid dapat menghalangi absorbsi besi.

Peneliti/enumerator memberikan telur ayam rebus dan buah pepaya dimulai dari hari senin hingga hari sabtu, Setelah diberikan telur dan pepaya, Hb posttest di periksa oleh peneliti pada hari senin menggunakan $\mathrm{Hb}$ digital yang dicatat dan kemudian dilakukan pengolahan data.

Seluruh data yang terkumpul selanjutnya dimasukkan (entry) dan ditabulasi sebagai hasil analisis. Perbedaan rerata dari kadar $\mathrm{Hb}$ sebelum dan sesudah diberikan intervensi yang berguna untuk mendapatkan gambaran umum dari masing-masing variabel yang diteliti. untuk melihat pengaruh telur ayam rebus dan buah pepaya dalam meningkatkan kadar hemoglobin atau mengurangi kejadian anemia, dimana sebelumnya dilakukan uji normalitas data yang dilakukan untuk mengetahui apakah data berdistribusi normal atau tidak. Data terdistribusi normal apabila memiliki nilai $p>0,05$ dan berdistribusi tidak normal apabila nilai $p<0,05$. Uji normalitas data dalam penelitian ini menggunakan uji Shapiro Wilk. Uji normalitas data didapatkan data berdistribusi normal karena memiliki $p$ value $>0,05$.

Hasil uji normalitas data diperoleh data bahwa skor rata-rata kadar hemoglobin sebelum dan sesudah diberikan telur ayam rebus dan buah pepaya mempunyai nilai signifikan masingmasing $(0,378$ dan 0,147$)$ yang nilainya lebih besar dari 0,05 sehingga data berdistribusi normal maka pengujian hipotesis dilanjutkan dengan menggunakan uji paired sample t test. Hasil dari penelitian yang dilakukan, didapatkan nilai $p$ value $\leq$ nilai $\alpha$, maka Ho ditolak, artinya ada Pengaruh Pemberian Telur Ayam Rebus dan Buah Pepaya terhadap peningkatan kadar Hemoglobin pada siswi SMP Negeri 22 Kerinci. Sebelum penelitian ini dilaksanakan karenamenyangkut keamanan dan kesejahteraan manusia sebagai subjek penelitian kesehatan maka penelitian ini sudah memperoleh Ethical Approval (persetujuan etik).

\section{HASIL DAN PEMBAHASAN}

Dewi Susanti, Faridah.Bd, Alsri Windra Doni,Yuli Amalia |158 


\section{Kadar Hemoglobin Siswi SMP Negeri 22 Kerinci Sebelum dan Sesudah Diberikan Perlakuan Tahun 2019}

Berdasarkan hasil analisis data distribusi rata-rata kadar hemoglobin siswi SMP Negeri 22 Kerinci sebelum diberikan perlakuan tahun 2019 diketahui bahwa rata-rata kadar hemoglobin pada siswi sebelum diberikan telur ayam rebus dan buah pepaya yaitu 10,456 gr\% dengan nilai minimal yaitu 9,4 gr\% dan nilai maksimal 11,1 gr\%. Sementara itu kenaikan kadar hb pada siswi anemia. Rata-rata kadar hemoglobin siswi SMP Negeri 22 Kerinci setelah diberikan telur ayam rebus dan buah pepaya yaitu 12,4 dengan nilai minimum kadar hemoglobin yaitu 11,0 gr\% dan nilai maximum kadar hemoglobin yaitu 13,4 gr\%.

\section{Tabel.1 Kadar Hemoglobin Siswi SMP Negeri 22 Kerinci Sebelum dan Sesudah Diberikan Perlakuan Tahun 2019}

\begin{tabular}{lccccc}
\hline \multicolumn{1}{c}{ VARIABEL } & N & MEAN & SD & MiN & MAKS \\
\hline SEBELUM PERLAKUAN & 16 & 10,456 & 0,4457 & 9,7 & 11,1 \\
SESUDAH DIBERIKAN PERLAKUAN & 16 & 12,412 & 0,7719 & 11,0 & 13,4 \\
\hline
\end{tabular}

Berdasarkan data diatas terdapat 16 responden yang mengkonsumsi telur ayam rebus dan buah pepaya selama 6 hari untuk meningkatkan kadar hemoglobin dikarenakan 16 responden tersebut masuk dalam kriteria inklusi dan ikut serta dalam penelitian hingga penelitian selesai, hal ini juga sejalan dengan perkiraan besar sampel yang menggunakan rumus Federrer.

Hasil penelitian ini sejalan dengan penelitian yang dilakukan oleh Sri Karyati yang berjudul "Pengaruh Konsumsi Telur Terhadap Peningkatan Kadar Hemoglobin Pada Remaja Putri yang Mengalami Anemia Di Kudus dimana rata-rata kadar Hb sebelum pada kelompok kontrol 10,12 dan pada kelompok intervensi 10,22 gr\%, dengan nilai minimal dan maksimal pada kelompok kontrol 9,40 dan 11,60 gr\%, sedangkan pada kelompok intervensi nilai minimal dan maksimal adalah 9,80 dan 11,10.(13) 
Penyebab anemia gizi besi pada remaja putri karena kurangnya asupan zat besi, perilaku makan dan minum, kehamilan remaja dan menstruasi. Remaja putri mengalami menstruasi setiap bulannya akan kehilangan darah kurang lebih 40-50 ml darah. Bila keadaan durasi masa menstruasi ini meningkat sampai 15\% maka dirinya akan kehilangan darah hingga mencapai 80-90 ml darah. Kejadian yang dialami remaja putri ini akan menyebabkan defisiensi besi yang apabila tidak segera diatasi akan mengakibatkan anemia kurang besi.(3,20) Kurangnya mengkonsumsi makanan yang memiliki zat besi heme seperti makanan yang bersumber hewani dan melewatkan sarapan sebelum berangkat kesekolah serta kurangnya mengkonsumsi makanan yang mengandung vitamin $\mathrm{C}$ juga ikut mempengaruhi $15-30 \%$ terjadinya anemia.(3)

Siswi SMP Negeri 22 Keinci cenderung banyak mengonsumsi makanan kemasan yang dijual dikantin sekolah, seperti mie instan, gorengan, bakso goreng dan berbagai makanan instan lainnya. Hal ini menjadi penyebab banyaknya frekuensi siswi yang mengalami anemia. Kurangnya pengetahuan, asupan makanan yang sedikit mengandung zat besi dan pola makan siswi yang cenderung sedikit dan suka memilih makanan. Ditambah dengan tidak adanya edukasi kepada siswi tentang pentingnya asupan gizi dan pola makan yang dapat meningkatkan kadar hemoglobin. Selain faktor lingkungan seperti kantin sekolah yang hanya menjual jajanan siap saji ataupun snack juga mempengaruhi siswi dalam meningkatkan asupan nutrisi yang seharusnya dipenuhi pada masa pertumbuhan remaja.Terutama bagi remaja putri, yang harus memenuhi kebutuhan zat besi, dikarenakan setiap bulan mengalami menstruasi.

Hasil penelitian ini sesuai dengan penelitian Karuniwati et al, bahwa rata-rata kenaikan kadar hemoglobin kelompok perlakuan pemberian 2 telur/hari dan vitamin C $75 \mathrm{mg}$ yaitu 1,71 gr\%, sedangkan pada kelompok pemberian 1 telur/hari dan vitamin C $75 \mathrm{mg}$ yaitu 1,58 gr\%, pada kelompok kontrol juga menunjukkan adanya kenaikan kadar hemoglobin yaitu 1,07 gr\%. Kesimpulannya adalah pemberian telur efektif untuk meningkatkan kadar hemoglobin pada ibu hamil yang mengalami anemia.(21) Kandungan protein didalam telur bermutu tinggi dan bersifat mudah dicerna, berbeda dengan makanan lain yang juga memiliki 
protein, telur memiliki susunan asam amino yang lengkap. Sehingga sangat baik dikonsumsi oleh anak-anak yang sedang tumbuh, ibu hamil dan menyususi, bahkan telur juga dianjurkan untuk diberikan pada orang yang sedang sakit untuk mempercepat proses penyembuhannya. Telur juga mengandung vitamin B kompleks, serta vitamin A dan D (dalam kuning telur). Mengandung banyak zat gizi yang sangat penting bagi kesehatan dan pencegahan penyakit. $(12,22)$

Sel darah merah mengandung hemoglobin yaitu protein yang membawa oksigen ke seluruh jaringan tubuh. Sumber protein berasal dari pangan hewani seperti susu, telur, daging, unggas, ikan dan kerang. Zat besi dalam makanan dapat berbentuk heme dan nonheme. Hasil dari suatu penelitian menunjukkan bahwa sebanyak 37\% zat heme dan 5\% zat nonheme yang ada dalam makanan dapat diabsorpi dan ditingkatkan dengan adanya asupan vitamin C. $(6,3)$

Vitamin C dapat diperoleh dari buah-buahan dan sayur-sayuran. Kandungan vitamin C dalam 100 gram pepaya sebanyak 78mg, selain vitamin C pepaya juga mengandung vitamin lainnya seperti vitamin A sebesar 365 SI (Satuan Internasional), vitamin V1 0,04 mg, kalsium $23 \mathrm{mg}$, hidrat arang 12,2 gr, fosfor $12 \mathrm{mg}$, besi $1,7 \mathrm{mg}$, protein $0,5 \mathrm{gr}$, air $86,7 \mathrm{gr}^{8},{ }^{14}$ Vitamin $\mathrm{C}$ dapat meningkatkan absorpsi zat nonheme sampai empat kali lipat.Vitamin $\mathrm{C}$ dengan zat besi membentuk senyawa askorbat besi kompleks yang larut dan mudah diabsorsi, karena itu vitamin $\mathrm{C}$ baik dikonsumsi bersama dengan zat besi untuk mencegah anemia.Vitamin $\mathrm{C}$ mereduksi zat besi feri menjadi ferodalamusus halus sehingga mudahdiabsorpsi.VitaminC menghambat pembentukan hemosiderin yangsukar dimobilisasi untuk membebaskan besibila diperlukan.Telur mengandung $60 \%$ besi nonheme. Absorbsi besi dalam bentuk nonheme meningkat 4 kali lipat bila ada vitamin C. $(7,18)$

Edukasi sangat bagus diberikan kepada remaja putri seperti penyebab terjadinya anemia pada remaja putri, akibat jika terjadi anemia pada remaja, dan cara mengatasi anemia. Selain memberikan edukasi, peneliti juga menganjurkan siswi untuk mengonsumsi tablet tambah darah yang diberikan oleh petugas kesehatan, menjelaskan cara mengonsumsi tablet 
tambah darah dan beberapa makanan ataupun minuman yang tidak boleh dikonsumsi bersamaan dengan tablet tambah darah.

\section{Tabel.2 Pengaruh Pemberian Telur Ayam Rebus dan Buah Pepaya terhadap Peningkatan Kadar Hemoglobin sebelum dan setelah Diberikan Perlakuan Pada Siswi SMP Negeri 22 Kerinci Tahun 2019}

\begin{tabular}{|c|c|c|c|c|c|}
\hline \multirow[t]{2}{*}{ VARIABEL } & \multirow[t]{2}{*}{ MEAN } & \multicolumn{2}{|c|}{$\begin{array}{c}\text { 95\% CONFIDENCE } \\
\text { INTERVAL OF THE } \\
\text { DIFFERENCE }\end{array}$} & \multirow[t]{2}{*}{ SD } & \multirow[t]{2}{*}{$\begin{array}{c}P \\
V A L U E\end{array}$} \\
\hline & & LOWER & UPPER & & \\
\hline SEBELUM DAN SESUDAH & $-1,9563$ & -2.2570 & -1.6555 & 0,5645 & 0,000 \\
\hline
\end{tabular}

Berdasarkan hasil statistik uji t dependen diperoleh nilai $p$ sebelum dan setelah diberikan telur ayam rebus dan buah pepaya yaitu nilai $p=0,000$ ( $p$ value $<0,05)$ yang berarti ada pengaruh pemberian telur ayam rebus dan buah pepaya dalam peningkatan kadar hemoglobin atau dengan kata lain telur ayam rebus dan buah pepaya bisa mengatasi anemia pada siswi SMP Negeri 22 Kerinci Tahun 2019.

Sesuai penelitian Sugita menunjukkan bahwa rata-rata kadar hemoglobin pretest dan posttest pada kelompok kontrol yaitu 12,633 gr/dl dan 12,413 gr/dl. Sedangkan kadar hemoglobin sebelum dan sesudah pada kelompok perlakuan yaitu 12,013 gr/dl dan 13,740 gr/dl. Sehingga terdapat perbedaan kenaikan kadar hemoglobin pada kelompok kontrol dan kelompok perlakuan dimana pada kelompok kontrol terdapat penurunan kadar hemoglobin yaitu sebesar 0,22 gr\%, sedangkan pada kelompok perlakuan terdapat rata-rata kenaikan kadar hemoglobin sebesar 1,727 gr\% dengan nilai $p$ value $=0,001(<0,05)$. Kesimpulannya adalah konsumsi telur ayam ras rebus efektif untuk peningkatan kadar Hb pada ibu hamil trimester II diwilayah kerja Puskesmas Klaten Tengah. Penelitian lain menunjukkan nilai rata-rata hemoglobin pada ibu hamil yang diberikan perlakuan dan dikontrol yaitu 10,838 gr/dL dan 10,010 gr/dL. Kesimpulannya adalah terdapat efektifitas pemberian pepaya (carica papaya l.) terhadap peningkatan kadar hemoglobin pada ibu hamil dengan anemia. 
Pemberian telur ayam rebus dan buah pepaya terbukti meningkatkan kadar hemoglobin. Kandungan protein yang lengkap pada telur dibandingkan dengan makanan hewani lainnya dan ditambah dengan buah pepaya yang memiliki jumlah vitamin $\mathrm{C}$ yang cukup untuk memenuhi kebutuhan per hari, merupakan kombinasi yang tepat dan juga aman dikonsumsi bagi remaja di pagi hari. Khomsan (2005) dalam Hardinsyah dan Aries (2012) mengatakan, bahwa sarapan yang mengandung sekitar 25\% kebutuhan gizi sehari merupakan upaya untuk memenuhi gizi seimbang, serta dapat memengaruhi daya pikir dan aktivitas seseorang dalam sehari, terutama pada anak yang sedang dalam masa pertumbuhan. ${ }^{4},{ }^{12},{ }^{16}$ Telur juga memiliki beberapa kelebihan yaitu, harga telur yang relatif terjangkau di kalangan masyarakat dengan ekonomi menengah kebawah. Telur ayam juga mudah ditemukan dan selain memiliki protein yang lengkap telur juga memiliki banyak vitamin yang terkandung didalamnya antara lain, vitamin C, vitamin A dan vitamin lainnya serta beberapa mineral dan lemak. Telur ayam juga banyak digemari karena rasanya yang lezat dan dapat dibuat menjadi berbagai campuran makanan dan di buat dalam berbagai bentuk seperti di goreng, direbus dan didadar.(10,11,22)

Tidak berbeda jauh dengan telur, pepaya juga memiliki banyak kelebihan yaitu, buah yang sangat kaya akan serat, berbagai vitamin (khususnya vitamin $\mathrm{C}$ dan $\mathrm{A}$ ), mineral, beta karotin (karotin) dan enzim (papain). Buah pepaya juga memiliki rasa manis sehingga banyak digemari diberbagai kalangan. Selain itu harga pepaya juga relatif murah dan terjangkau oleh berbagai kalangan. Tanaman pepaya mudah dibudidayakan sehingga mudah didapatkan. Buah pepaya juga berperan sebagai antioksidan untuk mencegah timbulnya kanker dan berbagai penyakit degeneratif.(11,14) Telur ayam rebus sangat mudah dibuat, begitu juga dengan buah pepaya efektif dan murah. Oleh karena itu diharapkan mengkonsumsi telur ayam rebus dan buah pepaya dapat menjadi alternatif bagi siswi dan petugas kesehatan dalam mengurangi angka kejadian anemia ringan karena remaja putri nantinya akan menjadi ibu yang melahirkan penerus bangsa. 


\section{SIMPULAN}

Kesimpulan dari penelitian ini adalah adanya pengaruh pemberian telur ayam rebus dan buah pepaya terhadap peningkatan kadar hemoglobin pada siswi SMP Negeri 22 Kerinci. Disarankan para guru siswi SMP Negeri 22 Kerinci yang mengalami anemia ringan untuk mengajak siswinya mengkonsumsi telur ayam rebus dan buah pepaya sebagai salah satu alternatif dalam mengatasi anemia ringan yang dialami siswi.

\section{DAFTAR PUSTAKA}

1. Kautshar Namchar, Dkk. Kepatuhan Ibu Hamil Dalam Mengonsumsi Tablet Zat Besi (FE) Di Puskesmas Bara-Baraya Tahun 2013. http://jurnalilmiah.ac.id. 2013;(Universitas Hasanuddin Makasar):80-89.

2. Indriani, Aisyah. Hubungan Status Gizi dengan Kejadian Anemia Pada Remaja Putri di SMAN 1 Kasihan. In: Http://Www.Digilib.Unisayogya.Ac.Id. ; 2018.

3. Fikawati, Sandra, Dkk. Gizi Anak Dan Remaja. Depok: PT Rajagrafindo Persada; 2017.

4. Yulindri. Hubungan Status Gizi dan Pola Menstruasi dengan Kejadian Anemia Pada Mahasiswa Prodi DIII Kebidanan Universitas Muslim Indonesia. jurnal.fkmumi.ac.id. 2018;(Universitas Muslim Indonesia). http;//jurnal.fkmumi.ac.id.

5. Isati, Sutanto Priyo Hastono. Determinan Kejadian Anemia Remaja Putri di SMP Negeri 22 Kota Jambi. online-journal.unja.ac.id. 2018;(Unja). http://online-journal.unja.ac.id.

6. Adriani, Merryana, dan Bambang Wijatmadi. Pengantar Gizi Masyarakat. Jakarta: PT Fajar Interpratama Mandiri; 2014.

7. Putra, Sitiativa Rizema. Gizi Dan Diet. Yogyakarta: D-Medika; 2013.

8. Arisman. Gizi Dalam Daur Kehidupan. Jakarta: EGC; 2010.

9. Auliana, Rizqie. Gizi Dan Penglolahan Pangan. Yogyakarta: Adicita Karya Nusa; 2001.

10. Kotzman, C A. Diet Makanan Terapis. Jakarta: PT Prestasi Pustakarya; 2007. 
11. Muchtar, Deddy. Pangan, Gizi, Dan Kesehatan. Bandung: Alfabeta; 2015.

12. Karyati, Sri, Dkk. Pengaruh Konsumsi Telur terhadap Peningkatan Kadar Hemoglobin Pada Remaja Putri Yang Mengalami Anemia di Kudus. Sekolah Tinggi Ilmu Kesehat Muhammadiyah Kudus. 2016:182-187. http://ppnijateng.org.

13. Sulistyowati, Yeny, Dan Eva Yuniritha. Metabolisme Zat Gizi. Yogyakarta: Transmedika; 2015.

14. Novitriyani, A. Aktivitas Antioksidan dan Kualitas Organoleptik Kopi Bubuk Nonkafein Dari Kombinasi Biji Pepaya dan Buah Nangka dengan Lama Penyangraian yang Berbeda. UMS. 2016. http://eprints.ums.ac.id.

15. Karuniawati, Benny dkk. Efektifitas Pemberian Telur Dan Vitamin C Terhadap Peningkatan Kadar Hemoglobin Pada Ibu Hamil Trimester III Di Wilayah Kabupaten Sleman. Karya Husada Yogyakarta. 2016. http://studylibid.com.

16. Notoatmodjo, Soekidjo. Metodologi Penelitian Kesehatan. Jakarta: Rineka Cipta; 2012.

17. Ersila, Wahyu, dan Lia Dwi Prafitri. Efektifitas Pemberian Tablet Zat Besi Ditambah Pepaya (Carical Papaya L.) Terhadap Peningkatan Kadar Hemoglobin Pada Remaja Putri Anemia DI Stikes Muhammadiyah Pekajang Tahun 2016. 4 th Univ Res Coloquium. 2016:74. http://publikasiilmiah.ums.ac.id.

18. Nusari, Dilla. Gambaran Kejadian Anemia Pada Remaja Putri SMP Negeri 18 Kota Bogor Tahun 2009.; 2010. http://repository.uinjkt.ac.id.

19. Putri, Rahima. Skripsi Pengaruh Konsumsi Jus Jambu Biji Merah Dan Telur Ayam Ras Rebus Terhadap Peningkatan Kadar Hemoglobin Pada Mahasiswi Prodi DIV Kebidanan Poltekkes Kemenkes RI Padang Tahun 2018. Padang; 2018.

20. Sugita, Supiati. Pengaruh Konsumsi Telur Ayam Ras Rebus Terhadap Peningkatan Kadar HB Pada Ibu Hamil Trimester II Di BPM Wilayah Kerja Puskesmas Klaten Tengah. J Poltekkes Solo. 2016;5:110-237. http://jurnal.poltekkes-solo.ac.id. 
SANITAS: JURNAL TEKNOLOGI DAN SENI KESEHATAN

21. Sarwono, Sarlito, W. Psikologi Remaja. Depok: PT Rajagrafindo Persada; 2018.

22. PT Trouw Nutrition. Trouw Nutrition. Eggducation.www.trouwnutrition.co.id. Published 2018. 